\title{
An Account of Money from the University of Michigan ${ }^{1}$
}

P. Mich.inv.306 verso

$30 \times 27 \mathrm{~cm}$

Arsinoite (?)

$127 / 128 \mathrm{CE}$

\section{Magdy A. I. Aly \\ Mansoura University}

\section{Introduction}

According to the records of the University of Michigan papyrus collection, this document ${ }^{2}$ is purchased in Egypt by B.P. Grenfell and F.W. Kelsey in March-April 1920. The papyrus is a fragmentary roll. It is light brown in color and of mediocre quality. The sheet is in a rather mutilated. The surface is rough and shows considerable abrasion and peeling off in several parts.

It is broken off at the right and lower edges. Regularly cut at the top side, with some breakage. Only some parts of its upper margin still preserved, which is about $2 \mathrm{~cm}$. There is a large diagonal lacuna at the middle. No folds can be seen in the papyrus. There is a strip of fiber between line 3 and line 4 in column 5 needs to be realigned to its proper

\footnotetext{
${ }^{1}$ The recto has been approved to be published in the forthcoming volume Michigan Papyri from the 1920 Kelsey-Grenfell Purchase (P.Mich.Cent.), which will be published by the end of 2020 and it dates back to127/128 CE and it is a list of payments in money.

${ }^{2}$ I would like to express my sincere appreciation towards our late colleague and friend Prof. Traianos Gagos, who gave me the chance to work under his supervision cataloging a part of the University of Michigan papyrus collection as well as giving me the permission to publish this document along with others. I would like very much also to thank my colleague and friend Prof. Arthur Verhoogt, the Associate Dean for Academic Programs and Initiatives for inviting me to participate in the special volume of editions of papyri from the University of Michigan papyrus collection to celebrate the first centennial of this collection (P.Mich.Cent.). As well as providing me with basic info about this papyrus.
} 
position. Some fibers have been frayed in several spots. It seems that the papyrus is generated from tomos synkollesimos, because there are two kolleses: one at ca. $7.5 \mathrm{~cm}$. from the left edge, the other can be seen at ca. $4 \mathrm{~cm}$ from the right edge, which leads us to thinking of, at least, another two missing columns (since the kollema contains about two or more columns). A relatively enigmatic wide vacat is being at the lower one-third of the sheet.

There is a thin layer of mud covers several parts of the verso. Some restoration can be done to realign the lower right portion of the papyrus to the proper position with the main portion. The text runs against the fibers in rather darker ink with a thick nib.

The hand is different from recto, it rather contracted and small-sized cursive. It is slow, expert, but careless with a tendency towards ligatures. The characteristics of the letters of verso show the following idiosyncrasies: the theta wide complete oval with prolonged horizontal stroke. The sigma has a shorter horizontal stroke unlike that on recto. The (5 obols) symbol drawn with an oblique stroke with two parallel dashes attached to the middle. The rho has a small descender without foot, while it represents in recto with long descender that invades the preceding line and ends with a wide foot. The text has a relatively wide dated heading that is wider than the other blocks of texts and may have been added later. It is also strength the idea of thinking of another missing column. According to the irregularity of entering the data, it seems that the document has 5 different columns. The preserved lines in the columns are 29, 19, 15, 25 and 25 in sequence.

Although some entries are almost linked together, yet it is more logic to put them in separate columns rather than one column, where some entries are not aligned together which led to thinking in separate columns was intended. Consequently, it is hard to declare that there is a pattern of intercolumniation spaces on verso. The interlinear spaces are rather small. The scribe has a tendency to ligature numerals (e.g. $\kappa \alpha, \kappa \beta, \kappa \Gamma$. etc). Due to the nature of the document, it has many monetary signs. There is one trema in line 90, but no other punctuation or diacritical marks. Neither Stichometry nor Colometry are attested in the document.

The text dates back to $128 \mathrm{CE}$. Except for the person names, no indication in the document refers to the provenance. This document seems to be an Account of temporary payments in amounts of money (not in-kind) and notes that seem to be related in some way to the contents of the recto $^{3}$. Most of the text is amounts of payments and contents a limited

${ }^{3}$ See: Magdy A.I. Aly, Account, P.Mich.Cent., Michgan, 2020 


\section{Magdy A. I. Aly}

number of person's names. It is worthy to mention that the preserved text has no indication for a total amount whether for each single column or the whole entries. As in recto the preserved names that have been mentioned in this account are overwhelming Arsinoite which point to the provenance of the document (See comments on lines 17, 20, 82, 84?, 89 and 108); the

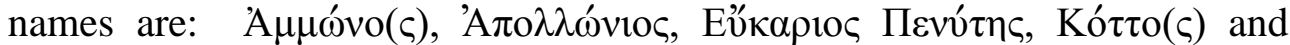

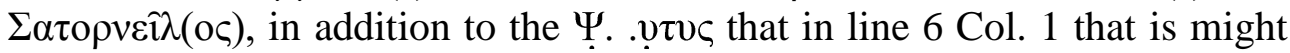
be another person's name. Although there are many "accounts of money", there is no precise parallel for this document in its content or general form.

\section{TRANSCRIPTION}

Col. 1

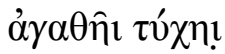

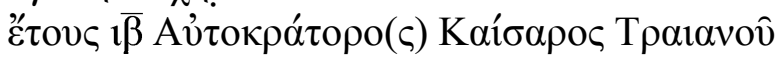

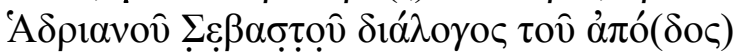

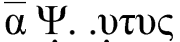

$$
\begin{aligned}
& 5-\quad \ldots \ldots \\
& \ldots \ldots \\
& (\delta \rho \alpha \chi \mu \grave{\alpha} \varsigma) \text { ic oc }(\delta \rho \alpha \chi \mu \grave{\alpha} \varsigma) \beta
\end{aligned}
$$

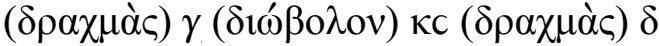

$$
\begin{aligned}
& \begin{array}{lll} 
& \kappa \alpha & (\delta \rho \alpha \chi \mu \grave{\alpha} \varsigma) \delta \\
10- & \kappa \alpha & (\delta \rho \alpha \chi \mu \alpha \varsigma) \delta
\end{array}
\end{aligned}
$$

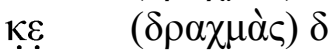

$$
\begin{aligned}
& \text { кূ } \quad(\delta \rho \alpha \chi \mu \alpha \varsigma) \delta \\
& \text { «c } \quad(\delta \rho \alpha \chi \mu \alpha \varsigma) \delta \\
& \text { Кс } \quad(\delta \rho \alpha \chi \mu \grave{\alpha} \varsigma) \delta
\end{aligned}
$$

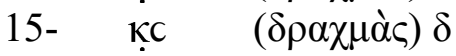

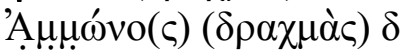

$$
\begin{aligned}
& \text { кс } \quad(\delta \rho \alpha \chi \mu \grave{\alpha} \varsigma) \delta
\end{aligned}
$$

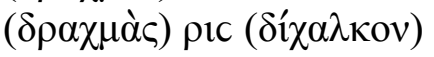

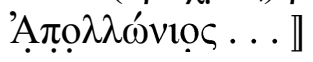

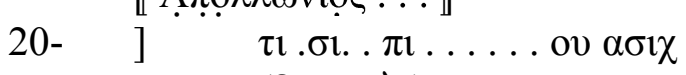

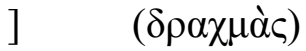


$\begin{array}{rll} & \text { ] ... } & (\delta \rho \alpha \chi \mu \grave{\alpha} \varsigma) \\ & ] & (\delta \rho \alpha \chi \mu \grave{\alpha}) \\ 25-\quad] & (\delta \rho \alpha \chi \mu \grave{\alpha}) \\ & ] & (\delta \rho \alpha \chi \mu \grave{\varsigma}) \\ & ] & \ldots \\ ] & \ldots \\ & & \ldots\end{array}$

Col. 2

\begin{tabular}{|c|c|c|}
\hline \multirow{4}{*}{$30-$} & & $(\delta \rho \alpha \chi \mu \grave{\alpha} \varsigma) \kappa$ \\
\hline & $o \bar{\beta}$ & 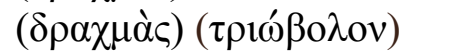 \\
\hline & $\kappa \gamma$. & 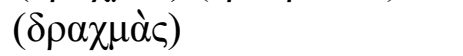 \\
\hline & $\alpha$. & $(\delta \rho \alpha \chi \mu \grave{\alpha} \varsigma)$ \\
\hline \multirow{5}{*}{$35-$} & $\kappa \mathrm{C}$ & $(\delta \rho \alpha \chi \mu \grave{\alpha} \varsigma)$ \\
\hline & $\kappa \mathrm{C}$ & $(\delta \rho \alpha \chi \mu \grave{\alpha} \varsigma) \delta$ \\
\hline & Кс & $(\delta \rho \alpha \chi \mu \grave{\alpha}) \beta$ \\
\hline & $\kappa \mathrm{C}$ & $(\delta \rho \alpha \chi \mu \grave{\alpha} \varsigma) c \quad\left(\delta^{\prime} \chi \alpha \alpha \lambda \kappa \sigma \nu\right)$ \\
\hline & $\kappa \mathrm{C}$ & 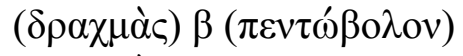 \\
\hline \multirow{5}{*}{$40-$} & $\kappa C$ & $(\delta \rho \alpha \chi \mu \grave{\alpha} \varsigma) \delta$ \\
\hline & $\kappa \mathrm{C}$ & $(\delta \rho \alpha \chi \mu \grave{\alpha} \varsigma) \delta$ \\
\hline & $\kappa \mathrm{C}$ & $(\delta \rho \alpha \chi \mu \grave{\alpha} \varsigma) \varepsilon$ \\
\hline & $\kappa \mathrm{C}$ & $(\delta \rho \alpha \chi \mu \grave{\alpha} \varsigma) \delta$ \\
\hline & $\kappa \mathrm{C}$ & $(\delta \rho \alpha \chi \mu \grave{\alpha} \varsigma) \delta$ \\
\hline \multirow{5}{*}{$45-$} & $\kappa \mathrm{C}$ & $(\delta \rho \alpha \chi \mu \grave{\alpha} \varsigma) \delta$ \\
\hline & $\kappa \mathrm{C}$ & $(\delta \rho \alpha \chi \mu \grave{\alpha} \varsigma) \delta$ \\
\hline & $\kappa \mathrm{C}$ & $(\delta \rho \alpha \chi \mu \grave{\alpha} \varsigma) \beta\left(\delta ı \omega^{\prime} \beta о \lambda о v\right)$ \\
\hline & $\kappa \mathrm{C}$ & $(\delta \rho \alpha \chi \mu \grave{\alpha} \varsigma) \delta$ \\
\hline & & $(\delta \rho \alpha \chi \mu \grave{\alpha} \varsigma) \eta$ \\
\hline
\end{tabular}

Col. 3

$$
\begin{aligned}
& \kappa \beta \quad(\delta \rho \alpha \chi \mu \grave{\alpha} \varsigma) \zeta
\end{aligned}
$$

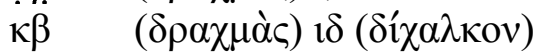

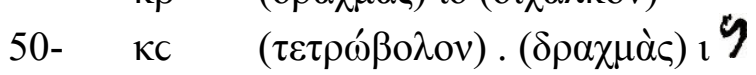

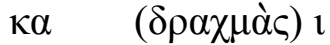

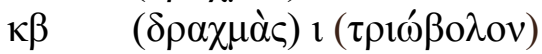

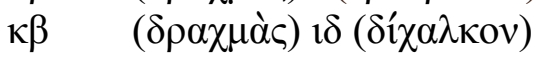

$$
\begin{aligned}
& \kappa \beta \quad(\delta \rho \alpha \chi \mu \grave{\alpha} \varsigma) \kappa c(\delta i ́ \chi \alpha \lambda \kappa o v) \\
& \text { 55- } \quad \kappa[.] \ldots(\delta \rho \alpha \chi \mu \alpha \varsigma) t \delta
\end{aligned}
$$

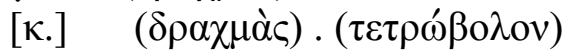


Magdy A. I. Aly

\begin{tabular}{|c|c|c|}
\hline \multirow{6}{*}{$60-$} & $<\rceil \beta$ & 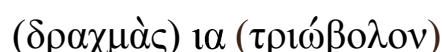 \\
\hline & {$[\kappa] \alpha$} & 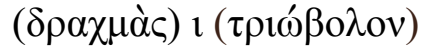 \\
\hline & $\kappa \beta$ & $(\delta \rho \alpha \chi \mu \alpha \grave{\varsigma}) v$ \\
\hline & $\kappa \beta$ & 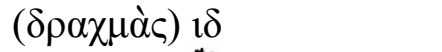 \\
\hline & {$[\kappa] \beta$} & $(\delta \rho \alpha \chi \mu \alpha \grave{\alpha})$ y \\
\hline & $\kappa$ & $(\delta \rho \alpha \chi \mu \grave{\alpha} \varsigma) \zeta$ \\
\hline
\end{tabular}

Col. 4

$$
\begin{aligned}
& \kappa \alpha \quad \text { ic } \\
& \kappa \alpha \quad(\delta \rho \alpha \chi \mu \grave{\alpha} \varsigma) 1 \\
& \text { 65- } \quad \kappa \alpha \quad(\delta \rho \alpha \chi \mu \alpha \grave{\varsigma}) y \\
& \kappa \alpha \quad(\delta \rho \alpha \chi \mu \alpha \varsigma) 1 \delta
\end{aligned}
$$

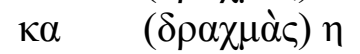

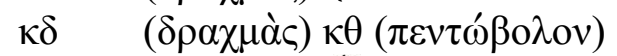

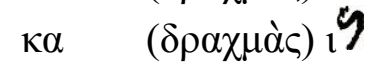

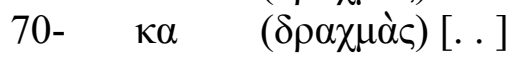

$$
\begin{aligned}
& \kappa \zeta \quad(\delta \rho \alpha \chi \mu \grave{\alpha} \varsigma) i \delta \\
& \kappa \alpha \quad(\delta \rho \alpha \chi \mu \grave{\alpha} \varsigma) 1 \varepsilon \\
& \kappa \alpha \quad(\delta \rho \alpha \chi \mu \grave{\alpha} \varsigma) 1 \alpha
\end{aligned}
$$

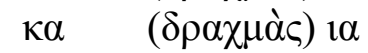

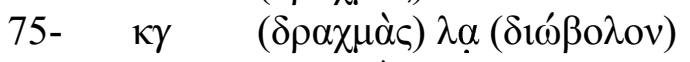

$$
\begin{aligned}
& \kappa \alpha \quad(\delta \rho \alpha \chi \mu \grave{\varsigma}) 1 \alpha \\
& \kappa \alpha \quad(\delta \rho \alpha \chi \mu \grave{\alpha} \varsigma) \eta \\
& \mu \alpha \quad \delta \eta \emptyset \\
& \alpha \quad(\delta \rho \alpha \mu \alpha \grave{\varsigma}) y \\
& \text { 80- } \quad \kappa \alpha \quad(\delta \rho \alpha \chi \mu \grave{\varsigma}) \zeta
\end{aligned}
$$

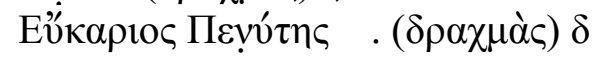

$$
\begin{aligned}
& \ldots \imath \tau \alpha \alpha(\delta \imath \omega ́ \beta \rho \lambda o v) \\
& \ldots . .(\delta \rho \alpha \chi \mu \grave{\varsigma} \varsigma) \delta \ldots \alpha()(\delta \rho \alpha \chi \mu \grave{\varsigma} \varsigma) \eta
\end{aligned}
$$

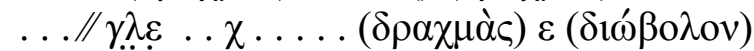

$$
\begin{aligned}
& \text { 85- } \quad \beta \kappa 1 \varepsilon(\delta \rho \alpha \chi \mu \grave{\alpha} \varsigma) \kappa \quad . \chi \varepsilon \rho . ~ .
\end{aligned}
$$

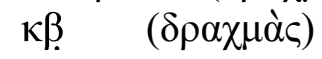

$$
\begin{aligned}
& \text {. . каро } \\
& (\delta \rho \alpha \chi \mu \alpha \grave{\varsigma}) \lambda \alpha
\end{aligned}
$$

Col. 5

$$
\begin{aligned}
& \text { Kó } \tau \backslash \backslash \mathrm{o} /(\varsigma) \quad \gamma \rho \alpha \mu \mu \backslash \alpha /(\tau \varepsilon v ́ \varsigma)
\end{aligned}
$$

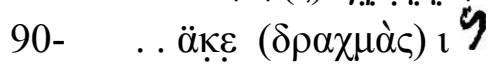




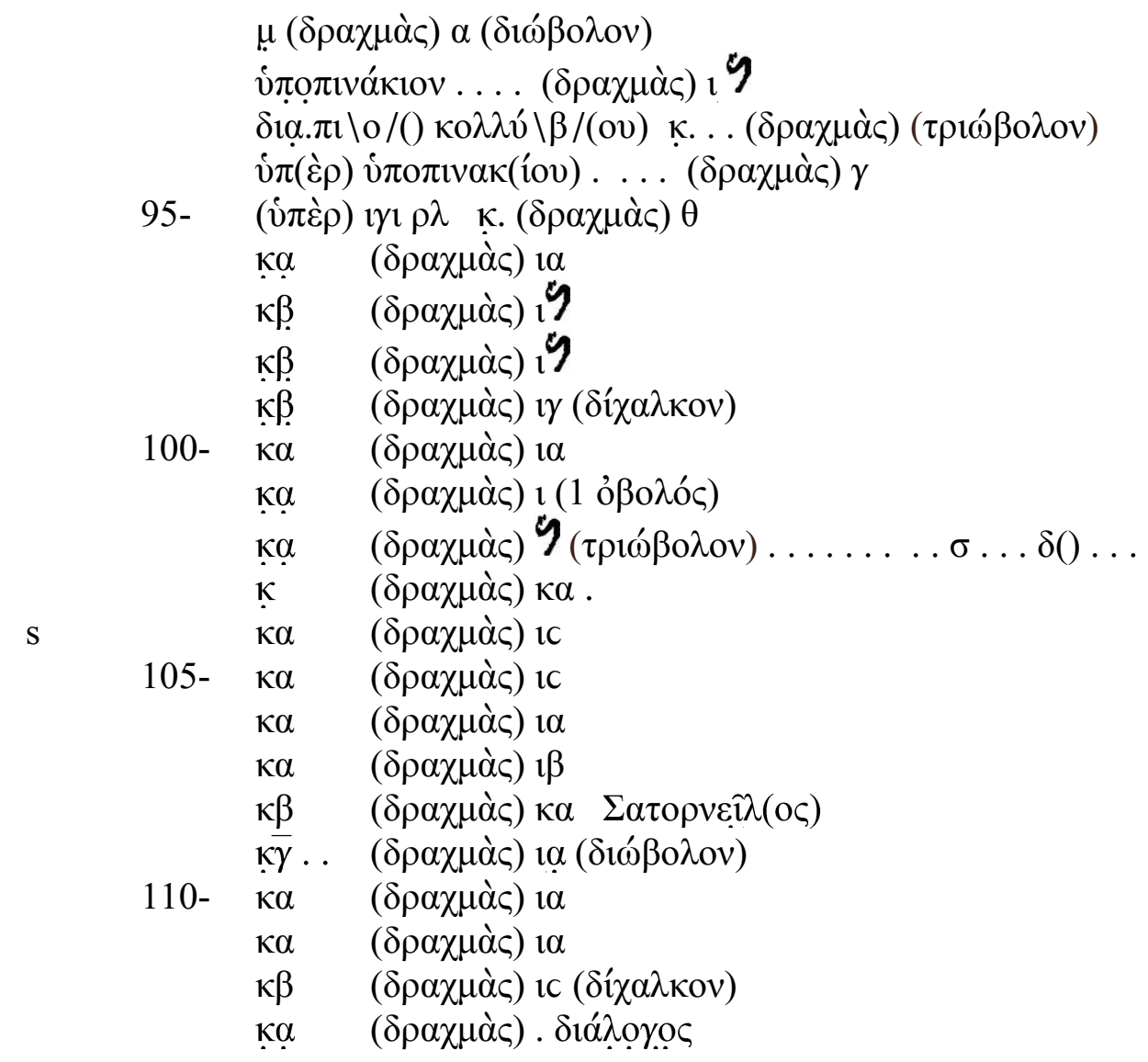

\section{Translation}

Verso

Col. 1

To the good fortune

The $12^{\text {th }}$ year of Emperor Caesar Trajan

Hadrian Augustus. The audit of the payment

1 Ps .. ytos

5 
Magdy A. I. Aly

16 drachmas 76, 2 drachmas

3 drachmas, 2 obols, 26, 4 drachmas

214 drachmas

10- $21 \quad 4$ drachmas

254 drachmas

254 drachmas

264 drachmas

15- $26 \quad 4$ drachmas

264 drachmas

Ammonios 4 drachmas

264 drachmas

116 drachmas, 2 chalci

20-

【 Apollonios ...】

ou asich

drachmas

... drachmas

drachmas

drachmas

25- drachmas

Col. 2

$\begin{array}{lll} & & \text { drachmas } 20 \\ 30- & 72 & \text { drachmas, } 3 \text { obols } \\ & 23 & . \text { drachma } 1 . \\ 1 . & \text {. drachmas } \\ 26 & \text {. drachmas } \\ & 26 & 4 \text { drachmas } \\ 35- & 26 & 2 \text { drachmas } \\ & 26 & 6 \text { drachmas, } 2 \text { chalci } \\ & 26 & 2 \text { drachmas, } 5 \text { obols } \\ 26 & 4 \text { drachmas } \\ 26 & 4 \text { drachmas } \\ 26 & 5 \text { drachmas } \\ 26 & 4 \text { drachmas } \\ 26 & 4 \text { drachmas } \\ 26 & 4 \text { drachmas }\end{array}$


$\begin{array}{lll} & 26 & 4 \text { drachmas } \\ 45- & 26 & 2 \text { drachmas, } 2 \text { obols } \\ & 26 & 4 \text { drachmas } \\ & & 8 \text { drachmas }\end{array}$

Col. 3

227 drachmas

2214 drachmas, 2 chalci

50- $26 \quad 10$ ? drachmas

$21 \quad 10$ drachmas

2210 drachmas, 3 obols

2214 drachmas, 2 chalci

$22 \quad 26$ drachmas, 2 chalci

55- [2.] 14 drachmas

[2.] . drachmas, 4 obols

[2]2 11 drachmas, 3 obols

$21 \quad 10$ drachmas, 3 obols

2213 drachmas

60- $22 \quad 14$ drachmas

[2]2 ? drachmas

227 drachmas

Col. 4

$\begin{array}{lll} & 21 & 16 \\ & 21 & 10 \text { drachmas } \\ 65- & 21 & ? \text { drachmas } \\ & 21 & 14 \text { drachmas } \\ & 21 & 8 \text { drachmas } \\ & 24 & 29 \text { drachmas, } 5 \text { obols } \\ & 21 & 10 ? \text { drachmas } \\ 70- & 21 & {[. .] \text { drachmas }} \\ & 27 & 14 \text { drachmas } \\ 21 & 15 \text { drachmas } \\ & 21 & 11 \text { drachmas } \\ & 21 & 11 \text { drachmas } \\ 75- & 23 & 31 \text { drachmas, } 2 \text { obols } \\ & 21 & 11 \text { drachmas } \\ 21 & 8 \text { drachmas }\end{array}$

$21 \quad 16$

2110 drachmas

2114 drachmas

218 drachmas

2429 drachmas, 5 obols

10 ? drachmas

$27 \quad 14$ drachmas

11 drachmas 
Magdy A. I. Aly

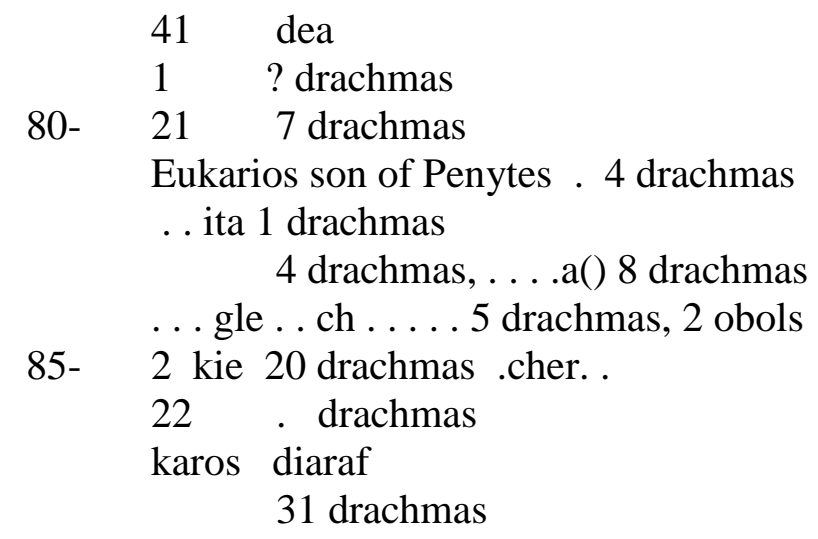

Col. 5

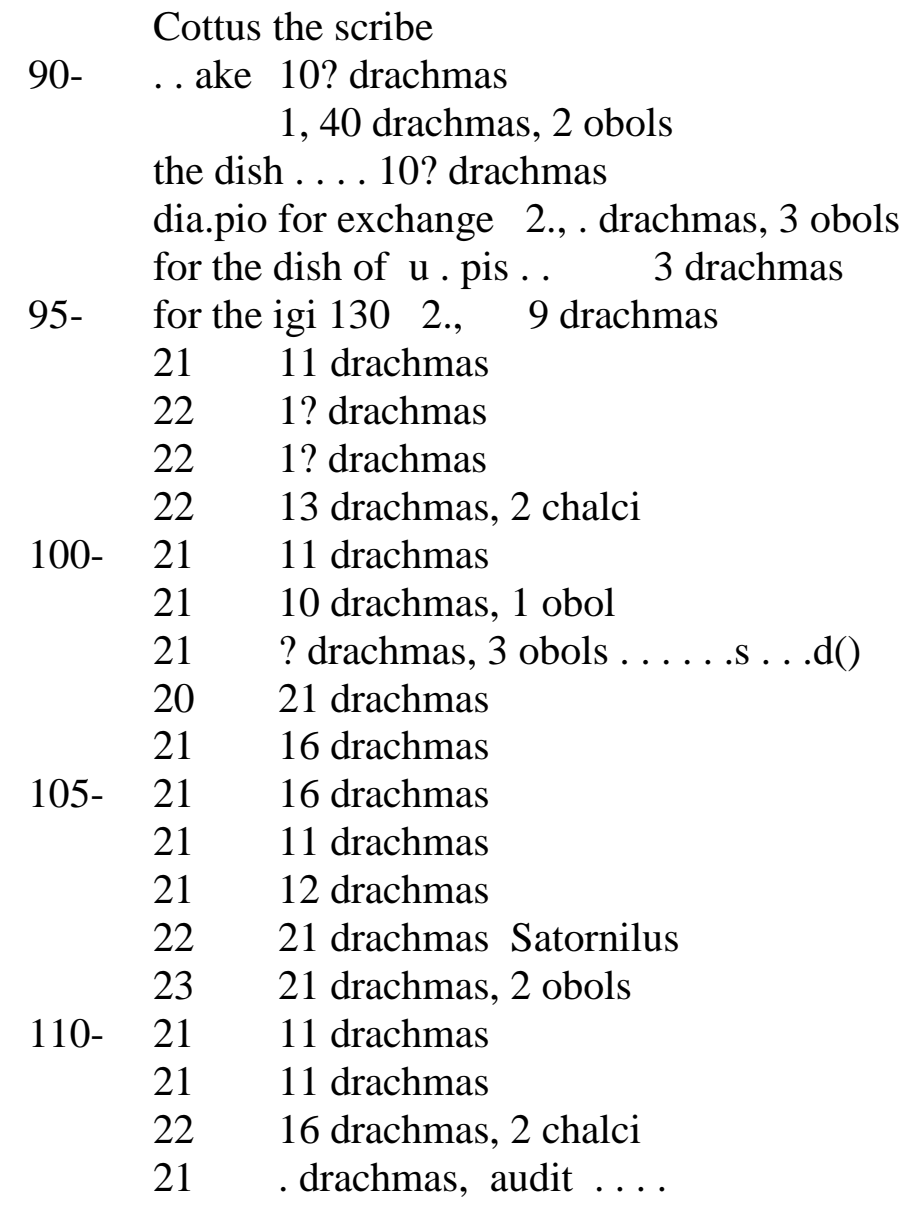




\section{Commentary}

Verso

Col. 1

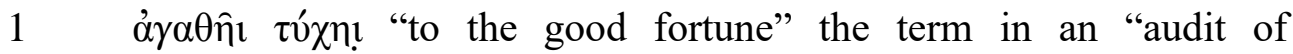
payments" might reflects a sort of anxiety or concern. Generally, this phrase is widely used in the documents regardless the type or chronology. The phrase has been attested as incipit can be concluded in the following of types documents: Exercise of an apprentice

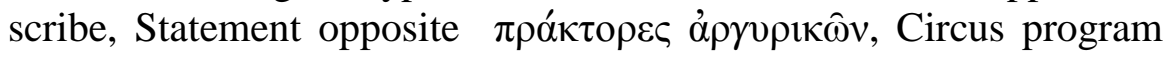
(without rides?), Testament, List of natural produce, Grapheion Register and Grapheion Accounts, List of Articles for a Sacrifice, Fishing Account, Marriage Contract and Evocation of happiness. They are found in the following documents:

p.mich 2 123, Grapheion Register and Grapheion Accounts, Tebtunis (Arsinoite), 45 CE - 46 CE, p.oxy 49 3495, Fishing Account, Oxyrhynchus, $101 \mathrm{CE}$ - $200 \mathrm{CE}$, sb 14 11393, Evocation of happiness, Arsinoite, $101 \mathrm{CE}$ - $200 \mathrm{CE}$, bgu 3 774, unknown, Arsinoite, $101 \mathrm{CE}$ - $200 \mathrm{CE}$, pap.choix 14, Statement opposite

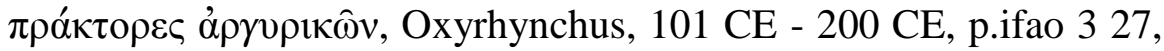
List, Arsinoite, 117 CE, p.koeln 12 487, Testament, Oxyrhynchus, 117 CE - 138 CE, cpr 5 2, Writing Practice, Ptolemais Euergetis (Arsinoite) , $134 \mathrm{CE}$ - $136 \mathrm{CE}$, bgu 20 2876, Exercise of an apprentice scribe, Arsinoite, $160 \mathrm{CE}$ - $161 \mathrm{CE}$, psi.congr.xvii 15, Horoscope, $181 \mathrm{CE}$, p.louvre 1 48, List of natural produce, Soknopaiu Nesos (Arsinoite), 212 CE, p.oxy 49 3500, Marriage Contract, Oxyrhynchus, $201 \mathrm{CE}$ - $300 \mathrm{CE}$, p.oxy 36 2797, List of Articles for a Sacrifice, Oxyrhynchus, $201 \mathrm{CE}-400 \mathrm{CE}$ and p.harrauer 56, CE, Circus program (without rides?), unknown, $501 \mathrm{CE}-600$.

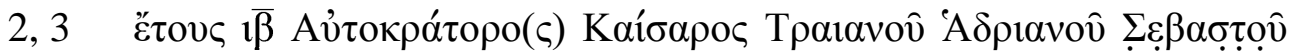

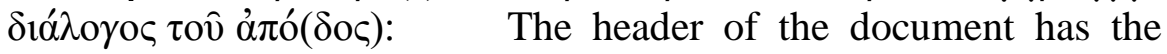
title of the document, year (i.e. 127/128 CE), emperor's title then should has month and day. 


\section{Magdy A. I. Aly}

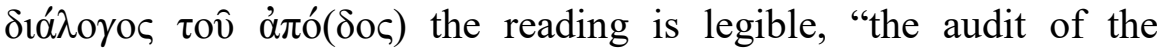
payment", although this phrase/ term has been attested in the documents so far, the phrase indicates the content of the document and even it reflects that the text "verso" is a draft for this audit.

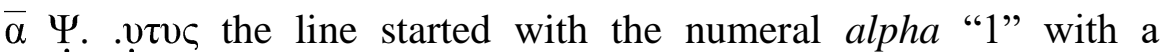
horizontal superscripted stroke. Both ascender and a part of the descender, as well as the cross stroke, are visible of the letter psi.

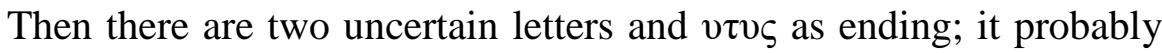
refers to a person name, yet it is hard to determine what it is.

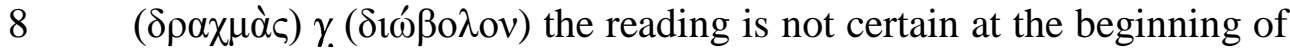
this line, yet the drachma symbol is clear and the descender of

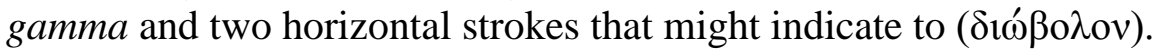

16 'A $\mu \mu \omega$ vo(ৎ) the first three letters are illegible then clear omega, nu and omicron. The name is attested about two hundred fifty times the majority are in Arsinoite.

$18](\delta \rho \alpha \chi \mu \grave{\alpha} \varsigma) \rho ! c$ ( $\delta$ í $\chi \alpha \lambda \kappa o v)$ : The smallest amount of money has been cited in verso is 2 drachmas (see line 36, col. 2), while the largest amount has been written in this line (116 drachmas and 2 chalci).

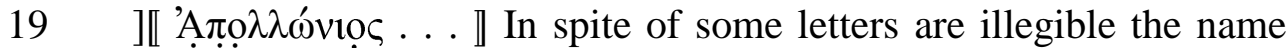
A $\pi \circ \lambda \lambda \omega ́ v 10 \varsigma$ fits for good restoration. One would expect drachma sign and a number, yet the fade ink and the cancellation strokes makes hard to see this. The scribe has crossed out the entire line as is erased.

Col. 3

$48 \quad \kappa \beta \quad(\delta \rho \alpha \chi \mu \grave{\alpha} \varsigma) \zeta$ the $k a b b a$ is not in a consistent form; nevertheless, it is compatible with the rest of the entries.

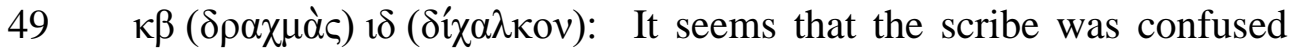
when he wrote the drachma sign with the letter zeta (7) in the preceding line that makes him to write the drachma sign reversely 2

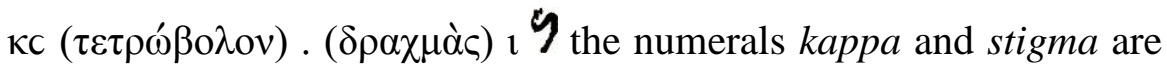
clear and the form comes afterwards mostly refers to 4 obols sign but the ink is partly washed out between the shoulder and the leg of the sign. There is a relatively problematical reading in this line represented in the tiny loop with a short stroke attached to the 
drachma sign that looks like an alpha, which does not match with the entry where it should refers to fraction smaller than obol (i.e. chalkos). Then the normal drachma sign followed by iota (10) then this enigmatic symbol $y$ come afterwards which logically, on one hand, should be either a unit (i.e. 1 to 9) or fraction of $\mathrm{obol} / \mathrm{s}$ or chalkos/i. On the other hand, there is no such sign for units or fractions in this form. The sign is similar to the koppa which is irrational after iota, or the fraction $1 / 8$ which is also cannot expected among all these amounts that in money not in kind. The form of eta " 8 " in the document (Cf.: Col. ii, 48, Col. iii, 51, 62, Col. iv, 66, 70, 80 , Col. v, 90, 92, 97, 98, 102) indicates undoubtedly that it is not intended!

$55 \kappa[$.$] . Like most of the entries in this column, it is very possible to$ have $\beta$ in the missing part.

$56[\kappa$.$] the missing part is mostly has the letter/numeral " \kappa$ " as all the other entries in the same column and most of the other columns as well.

$57 \quad[\kappa] \beta$ for the restoration of the kappa see previous comment.

Col. 4

From the way of writing the lines of column 4 (i.e. Superscripted, add scripted and contracted letters), It is clearly that the scribe has entered these entries subsequently.

$78 \mu \alpha \delta y \alpha$ after the number 41 , the first letter looks like delta, then contracted and reversed $n u$ and the superscripted legible alpha. va stand for a logic expected numeral entry. The delta still has no sense except for it might be an unusual abbreviation of $\delta\left(\rho \alpha \chi \mu \alpha \alpha^{\prime}\right)$, the only

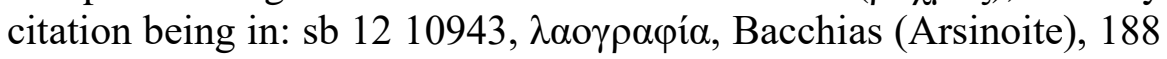
CE.

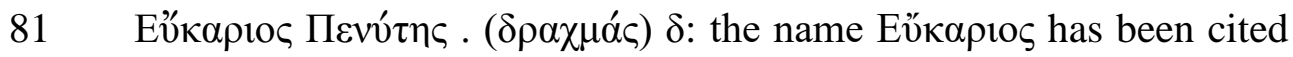
once bgu 2 618, unknown, Mendes (Arsinoite), 213 CE - $214 \mathrm{CE}$ nevertheless it was restored and it is in diminutive form

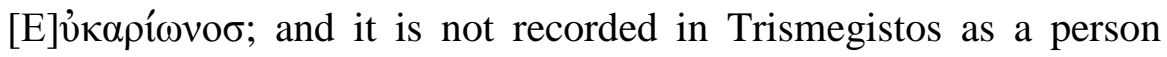

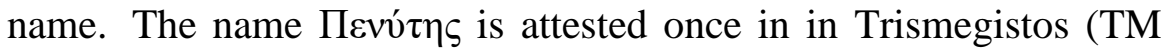

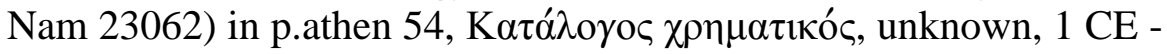




\section{Magdy A. I. Aly}

$400 \mathrm{CE}$. Consequently, this person has not cited elsewhere in the documents.

84

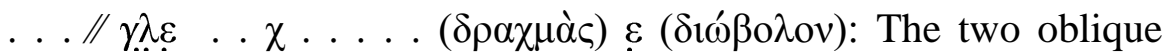
strokes located at the beginning of line 84 stand for a cancellation mark and mostly intended to cancel the entire entry. According to the abrasion of the ink and the frayed fibers the reading is illegible and unclear. Yet, it is expected to see a person name.

Col. 5

89 Kó $\tau \backslash \mathrm{o} /(\varsigma) \gamma \rho \alpha \mu \mu \backslash \alpha /(\tau \varepsilon v ́ \varsigma)$ : Kó $\tau \tau o \varsigma$ has been cited in Trismegistos (TM Nam 9976) as a main name14 times, and once as double name

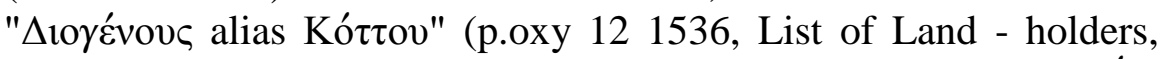
Oxyrhynchus, $101 \mathrm{CE}$ - $200 \mathrm{CE}$ ) and once as triple name "Гaí́oc

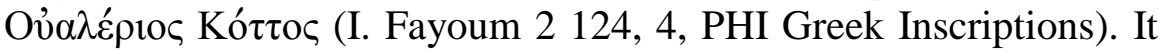
is quite possible that the same person could be the same mentioned in: p.mich 3180 and 181, Declaration of Property, Bacchias (Arsinoite), $131 \mathrm{CE}$.

$\gamma \rho \alpha \mu \mu \backslash \alpha /(\tau \varepsilon v ́ \varsigma)$, parts of some letters of the word such as gamma and rho are clear, and the ended with the superscripted alpha. It worthy to mention that the word has been abbreviated almost in all its parts (i.e. letters/ syllables) as follow:

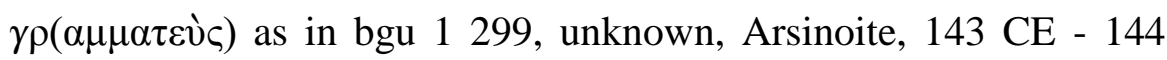
CE, $\gamma \rho \alpha(\mu \mu \alpha \tau \varepsilon v 0 \mathrm{v})$ as in bgu $3891 \mathrm{v}$, unknown, Andromachis

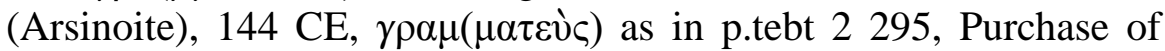
Priestly Offices, Tebtunis (Arsinoite), 126 CE - 138 CE, $\gamma \rho \alpha \mu \mu(\alpha \tau \varepsilon v ́ \varsigma)$ as in p.dubl 8, Declaration to a Strategos, Ptolemais

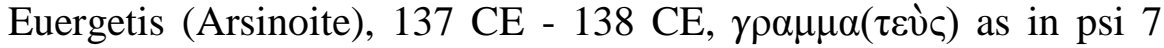
766, Fragment of relationship of grammateis and komogrammateis,

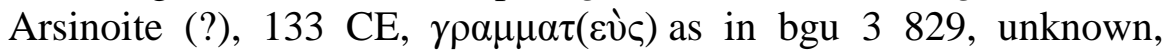
Arsinoite, $110 \mathrm{CE}$, and $\gamma \rho \alpha \mu \mu \alpha \tau \varepsilon(\hat{v} \sigma \mathrm{l})$ as in c.pap.gr 2.123 , Death report, Ptolemais Euergetis (Arsinoite), 108 CE.

$90 \ldots \ddot{\alpha} \kappa \varepsilon(\delta \rho \alpha \chi \mu \grave{\alpha} \varsigma) \rho$ there is a diaeresis over the second letter in the line or over the alpha. No suggested restoration for this word.

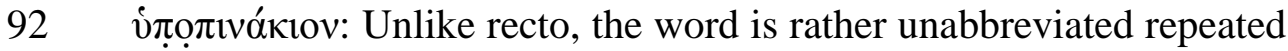
in verso. It is hapax compound from the diminutive of $\pi \dot{i} v \alpha \xi$. The 


\section{An Account of Money from the University of Michigan}

use of the word is wide (See: $\mathrm{LSJ}^{4}$ ); but since there are some words in recto such as: $\mu \alpha v \delta \eta \dot{\lambda} \lambda 1 \alpha$ ("hand towels" or "handkerchiefs") and one for $\beta \alpha \lambda \alpha v \alpha$ pia ("bath towels,"), it is possible refers here to "dish/s".

$93 \delta 1 \alpha . \pi \mathrm{i} \backslash \mathrm{o} /() \kappa \mathrm{o} \lambda \lambda v \backslash \beta /(\mathrm{ov})$ there is no any attestations in PN for a construction of a phrase of кó $\lambda \lambda v \beta o \varsigma$ preceded by a word started with $\delta 1 \alpha \ldots$ !

95 (i $\pi \grave{\varepsilon} \rho)$ ) $\gamma \imath \rho \lambda$ : although the entry of this line is limited and the reading in is legible whether the proposition ( $\dot{v} \pi \dot{\varepsilon} \rho)$ or the number $\rho \lambda$ " 130 ", or even the letters in between, there is no rational restoration for a word begins with $1 \gamma \imath$ and preceded by $i \pi \varepsilon ́ \rho$.

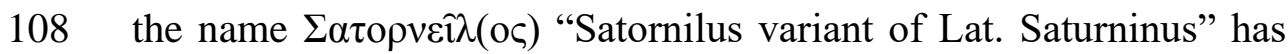
been cited 290 times in Trismegistos (TM Nam 11970), 19 times in Arsinoite nome.

\footnotetext{
${ }^{4}$ Henry George Liddell. Robert Scott. A Greek-English Lexicon. revised and augmented throughout by. Sir Henry Stuart Jones. with the assistance of. Roderick McKenzie. Oxford. Clarendon Press with 2005.
} 


\section{Magdy A. I. Aly}

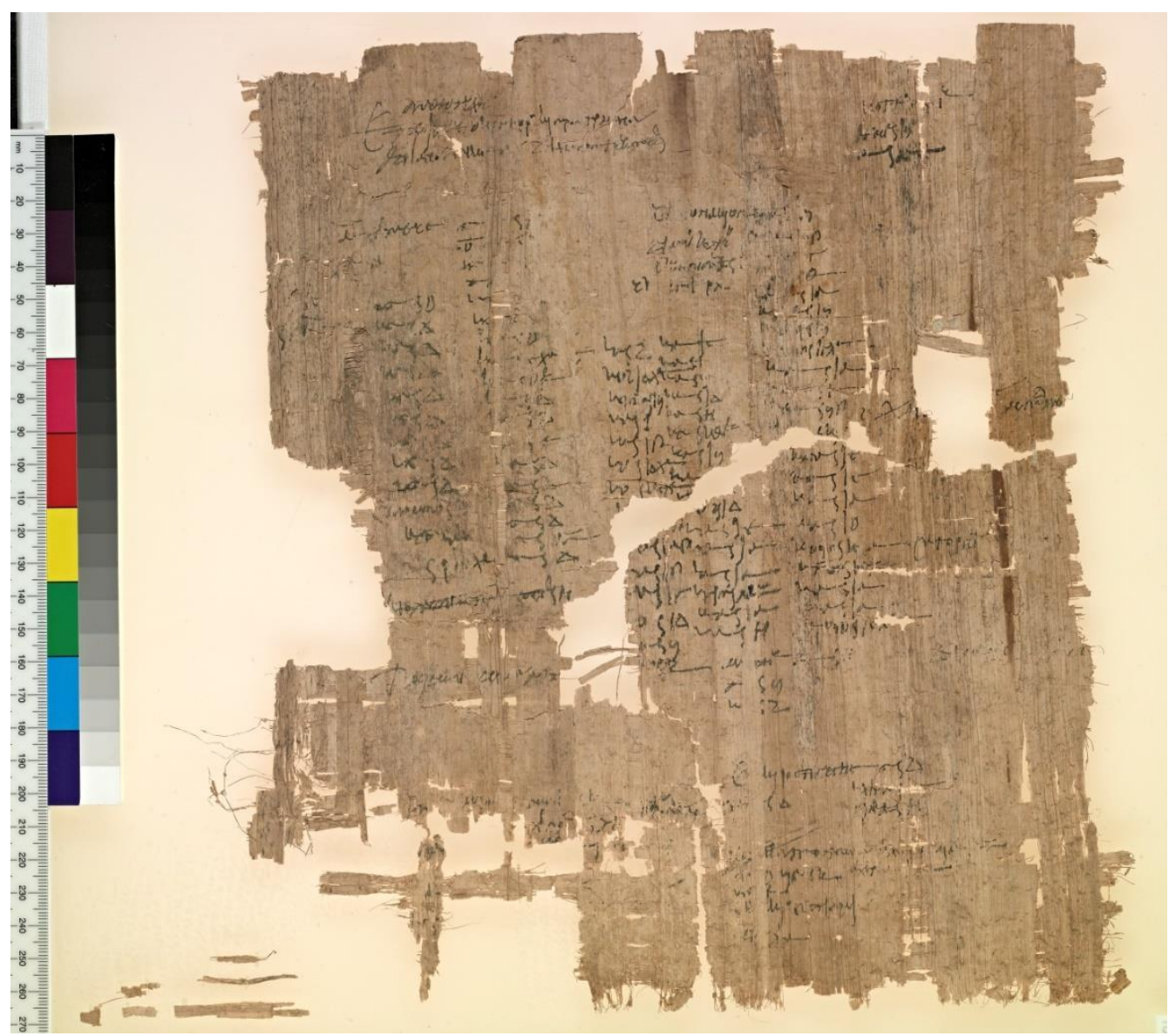

P. MICH.INV.306, VERSO

\section{REFERENCES}

- BGU, = Aegyptische Urkunden aus den Königlichen (later Staatlichen) Museen zu Berlin, Griechische Urkunden. Berlin.

- I. Fayoum, PHI Greek Inscriptions.

- CPR, = Corpus Papyrorum Raineri. Vienna.

- P.Athen., = Papyri Societatis Archaeologicae Atheniensis, ed. G.A. Petropoulos. Athens 1939. (Pragmateiai tês Akademias Athênôn 10). Nos. 1-70. [MF 1.64; rp. CG]. Further texts published in Anekdotoi 
philologikoi kai idiôtikoi papyroi, ed. M.G. Tsoukalas. Athens 1962. (Bibliothêkê tês en Athênais Philekpaideutikês Hetaireias 17); reprinted in SB VIII 9860-9862.

- P.Dubl., = Greek Papyri from Dublin, ed. B.C. McGing. Bonn 1995. (Pap.Texte Abh. XLII). Nos. 1-34.

- P.Harrauer, = Wiener Papyri als Festgabe zum 60. Geburtstag von Hermann Harrauer, ed. B. Palme. Vienna 2001. Nos. 1-62. Nos. 1-3, 28-36, 38-45, 47-56 and 58-60 are Greek. Nos. 4 and 57 are Coptic. Nos. 5-11, 1215 and 32-33 are Demotic. No. 37 is Latin. No. 61 is Arabic. Nos. 26-27 are Demotic and Greek. No. 46 is Greek and Latin. No. 62 is a medieval bilingual glossary (Latin/Greek).

- P.IFAO, = Papyrus grecs de l'Institut Français d'Archéologie Orientale. Cairo. (Institut Français d'Archéologie Orientale du Caire. Bibliothèque d'Étude).

- P.Louvre, I, Griechische Papyri aus Soknopaiu Nesos, ed. A. Jördens mit Beiträgen von K.-Th. Zauzich. Bonn 1998. (Pap.Texte Abh. XLIII). Nos. 1-92; 69-92 are descripta.

- P.Mich., = Michigan Papyri. Each volume has a subtitle of its own. The numerical sequence of volumes as a single series was not established until vol. II.

- P.Oxy. The Oxyrhynchus Papyri. Published by the Egypt Exploration Society in Graeco-Roman Memoirs. London. The number in parentheses at the end of each entry is the number in this series. Earlier vols. carry the heading of Egypt Exploration Fund, Graeco-Roman Branch; even after the title change numbers were not assigned to the volumes until the 1950s.

- P.Tebt., = The Tebtunis Papyri. London., I, ed. B.P. Grenfell, A.S. Hunt and J.G. Smyly. 1902. (Univ. of California Publications, Graeco-Roman Archaeology I; Egypt Exploration Society, Graeco-Roman Memoirs 4). II, ed. B.P. Grenfell and A.S. Hunt. 1907. (Univ. of California Publications, Graeco-Roman Archaeology II). Reprint 1970. (Egypt Exploration Society, Graeco-Roman Memoirs 52).

- Pap.Choix, = Choix de papyrus grecs: Essai de traitement automatique, ed. J. Bingen, A. Tomsin, A. Bodson, J. Denooz, J.D. Dupont and E. Evrard. Liège 1968. 28 miscellaneous texts revised and republished.

- PSI, = Papiri greci e latini. (Pubblicazioni della Società Italiana per la ricerca dei papiri greci e latini in Egitto). Florence. The first eleven volumes were edited by a number of persons under the general direction of G. Vitelli and M. Norsa. A list of reeditions of documentary texts is given by $\mathrm{P}$. Pruneti in Pap.Flor. XIX.2, pp. 475-502. Volumes 16- are published under 


\section{Magdy A. I. Aly}

the title Papiri della Società Italiana in the series Edizioni dell'Istituto papirologico G. Vitelli.

- SB, = Sammelbuch griechischer Urkunden aus Aegypten. (A collection of documentary papyri, ostraca, inscriptions, mummy tablets and related texts published in journals or unindexed catalogues. Begun by F. Preisigke in 1915, continued by F. Bilabel, E. Kiessling, and H.-A. Rupprecht).

- Henry George Liddell. Robert Scott. A Greek-English Lexicon. revised and augmented throughout by. Sir Henry Stuart Jones. with the assistance of. Roderick McKenzie. Oxford. Clarendon Press. 1940.

- Magdy A.I. Aly, Account, P.Mich.Cent., Michgan, 2020.

- Henry George Liddell. Robert Scott. A Greek-English Lexicon. revised and augmented throughout by. Sir Henry Stuart Jones. with the assistance of. Roderick McKenzie. Oxford. Clarendon Press with 2005.

Online Resources:

- PN, Papyrological Navigator. Papyri.info

- TM, Trismegistos, trismegistos.org 